NBER WORKING PAPER SERIES

INTERNATIONAL DEBT SERVICE

AND ECONOMIC GROWTH:

SOME SIMPLE ANALYTICS

Martin Feldstein

Working Paper No. 2076

NATIONAL BUREAU OF ECONOMIC RESEARCH

1050 Massachusetts Avenue

Cambridge, MA 02138

November 1986

I am grateful for discussion of the international debt problem with Jeffrey Franke1, Paul Krugman and Jeffrey Sachs. The research reported here is part of the NBER's research program in International Studies. Any opinions expressed are those of the author and not those of the Nationa? Bureau of Economic Research. 
NBER Working Paper \#2076

November 1986

\title{
International Debt Service and Economic Growth: Some Simple Analytics
}

\begin{abstract}
Any arrangement that is to serve as a long-term framework for international debt management must permit a politically acceptable rate of economic growth in the debtor countries while gradually improving the financial positions of the creditor banks. In addition, a realistic debt management strategy must maintain enough new lending to the debtor countries to provide an incentive for continued compliance with debt service responsibilities.

This paper establishes the conditions under which these three goals are compatible. The analysis indicates that Argentina, Brazil and Mexico are now all capable of achieving significant rates of economic growth without debt write-downs or interest rate reductions. They do require additional amounts of credit but the resulting increases in the absolute size of their debts is compatible with declining ratios of debt to their own exports and to the total earnings of the creditor banks. Stated differently, limiting the ratio of debt service payments to GNP to country-specific standards, whether by long-term agreements or by annual negotiations, can achieve economic growth while improving the financial conditions of the creditor banks.
\end{abstract}

Martin Feldste in

Nationa 1 Bureau of Economic Research 1050 Massachusetts Avenue

Cambridge, MA 02138 


\section{International Debt Service and Economic Growth: \\ Some Simple Analytics}

Martin Feldstein*

The management of the international debt problem has now reached a new phase. The first two years of crisis management that began in August 1982 were followed by two years of country-by-country debt rescheduling. Although this process has worked better than many expected four years ago, substantial uncertainty about the future evolution of the debt problem remains.

It is now clear that the process of bringing the debtor countries back to the condition in which they have voluntary access to bank borrowing and private capital markets will be at best slow and difficult. The critical problem is to move to that goal in a way that avoids either unilateral debt repudiation by borrowers or unilateral credit interruption by lenders.

Any such major break from the existing cooperative approach to debt management could have very serious adverse effects on both the developing and industrialized nations. The interruption of credit to the developing countries would mean a sharp decline in trade finance and an economic downturn. Unilateral debt repudiation could put serious strains on the banking systems of the industrial creditor countries, particularly the United

*Professor of Economics, Harvard University, and President, the National Bureau of Economic Research. I am grateful for discussion of the international debt problem with Jeffrey Franke1, Paul Krugman and Jeffrey Sachs. This paper is part of the NBER Project on International Debt. 
States. The political consequences of a collapse of cooperation and the imposition of punitive sanctions could be as important as the economic ones. Maintaining that cooperation can be facilitated by agreement, either explicit or implicit, on a long-term strategy that recognizes and controls the burdens on both borrowers and creditors. More specifically, any arrangement that is to serve as a long-term framework for international debt management must permit a politically acceptable rate of economic growth in the debtor countries while gradually improving the financial position of the creditor banks. In addition, a realistic debt management strategy must maintain enough new lending to the debtor countries to provide an incentive for continued compliance with debt service responsibilities.

The purpose of the present paper is to examine whether the strategy of limiting annual debt service payments to a fixed fraction of the debtor country's gross national product (either by long-term agreement or by annual negotiation) is in principle compatible with these three goals of long-term debt management. After discussing the analytic links among these goals, the paper presents some calculations for Argentina, Brazil and Mexico.

The emphasis in the current analysis is on the long-term compatibility of the three goals rather than on the current cyclical situation. In an early and influential study, Cline (1983) showed that the likely cyclical upturn in economic activity in the major industrial countries in 1983-84 would raise the exports of the LDC debtor countries by enough to reduce their debt to export ratios at the same time that the debtors were raising their own levels of domestic output. The cyclical experience since then has generally borne out Cline's optimistic projections (Cline, 1985). 
It important however to look beyond the short-term cyclical analys is to see whether conservatively estimated performance of the debtor countries is consistent with the three goals over the longer term. For example, cline's analysis was based on the cyclical relation that an extra one percent of GNP growth in the OECD countries would raise debtor country exports by approximately three percent and significantly increase the real prices of those exports. While this type of relation can hold in a cyclical expansion, it obviously cannot be sustained in the long term. Similarly, although in the short run each additional one percent rise in the debtor country's GNP requires its imports to rise by approximately three percent, the long-term import elasticity with respect to GNP is approximately one (Cline, 1983). The present paper focuses therefore on the issue of long-term compatibility and is thus a complement to $\mathrm{Cline's} \mathrm{short} \mathrm{term} \mathrm{analys} \mathrm{is.}$

Before turning to the formal analysis, it is useful to comment further on the three goals that must be balanced in any feasible plan.

\section{Three Goals of Debt Management}

The burden faced by the debtor countries is not just freeing the domestic resources to service their international debt obligations but, more importantly, doing so in a way that converts those resources into foreign exchange. Although the major debtor countries should eventually be able to achieve this by expanding their exports, experience has shown that increasing exports is difficult and suggests the conservative assumption that the long-term growth of exports will simply maintain the current ratios of exports to GNP. To the extent that the debtor countries grow more rapidiy than the 
industrial economies, even this "conservative" assumption implies that the ratio of imports from the debtor countries to the GNP's of the industrial countries will rise over time. With a fixed ratio of exports to GNP, changes in debt service requirements imply corresponding changes in imports.

A lower level of imports not only directly reduces domestic consumption but also decreases the feasible level of real GNP. These adverse effects of an increase in debt service are not only a potential hardship for the people of the debtor countries but also limit the politically feasible amount of debt service in democratic regimes.

The political problem of maintaining debt service is substantially exacerbated when a debtor country is no longer receiving any net additional credit from its bank creditors. In that situation, the debtor country must achieve a trade surplus large enough to meet all of the accruing nominal interest obligations. Despite the obvious legal legitimacy of requiring timely interest payments, this may put an impossible burden on the political leaders of a country that sees itself called upon to service its debt with no additional help from the creditors. In the most extreme case, the debtor country may repudiate its debt obligation unless it receives a net inflow of resources from the creditor countries, i.e., unless the amount that it is receiving in the form of commercial loans and other transfers is enough both to meet its interest obligations and also to finance additional net imports of goods.

For the banks, the problem is that the existing high ratios of international debt to net bank capital and to bank earnings and the uncertainty about the future ability of the debtor countries to service their 
debts has caused a deterioration of the credit-rating of the major banks themselves. 1 The resulting increase in the cost of funds to the banks (i.e., the interest rates that the banks have to pay on their large certificates of deposit) encourages disintermediation: the most creditworthy domestic nonbank firms can borrow more cheaply by issuing their own commercial paper than by borrowing from the banks at the most favorable rates that the banks can afford to offer. The deteriorating credit quality of the banks' domestic loans exacerbates the banks' own credit standing and increases the risk of a cumulative process that could lead to runs on major banks.

The banks can reduce this risk by increasing their capital base through equity issues and by increasing the share of earnings that are retained. But new equity capital is itself expensive 2 and the process of distintermediation may continue unless the banks and their creditors can look forward to a declining relative size of the international debt and improved prospects of future debt service.

In short, the debtor countries are seeking smaller annual debt service payments in order to permit faster growth and a more favorable annual net resource flow while the banks want larger annual debt service payments in order to reduce their relative exposure and convince their creditors that their loans to the debtor countries can be serviced. Reconciling these conflicting aims is the essence of the problem of international debt management. A long-term plan that balances these conflicting aims in a way that is acceptable to both the borrowers and their creditors would bring increased opportunities for economic growth in the debtor countries and greater stability to the financial markets of the industrial countries. 
A formal version of the plan analyzed in the present paper would limit each country's future annual debt service payments to an agreed fraction of that country's gross national product with any excess debt service obligation added to the principal of the loan. ${ }^{3}$ Such a GNP-capping arrangement would in effect formalize the existing ad hoc procedure of rescheduling principal payments and providing new credit to offset part of the interest obligations. Whether done by a long-term agreement or by annual negotiations, such a limit on debt service could, under conditions that are likely to prevail in a large number of the debtor countries, reconcile the conflicting aims and satisfy the three key goals of permitting strong GNP growth in the debtor country, providing sufficient net new lending to debtor countries from creditor banks, and increasing bank creditworthiness by establishing downward trends for the ratios of LDC debt to bank assets and earnings and to the exports and GNPS of the debtor countries.

Under the conditions specified below, these three aims can be satisfied without additional net lending from the IMF and World Bank and without the injection of funds from the governments of the industrialized countries. Nor is it generally necessary to write off debt, shift to a policy of below-market interest rates, or do other things that would put U.S. banks in violation of U.S. regulatory procedures. ${ }^{4}$ Although the conditions of the debtor countries and the banks could obviously be ameliorated by increased official lending, by the repatriation of flight capital, and by increased direct foreign investment, none of these is in general necessary for combining economic growth with improved bank conditions. There are, however, circumstances that could prevail in some countries that would make it impossible to reconcile 
these three goals without the infusion of official funds or other types of additional foreign exchange; the analysis indicates the nature of these conditions.

Fixing annual debt service costs as a percentage of the debtor country's GNP has very different incentive effects from the proposals to limit debt service to a percentage of the country's export earnings. 5 Because the exports of a typical debtor country are only a small fraction of that country's GNP, a debt service requirement that would be only a small percentage of the debtor country's GNP would be a large enough percentage of exports to be a significant disincentive to increased exporting. In Brazil, for example, debt service payments of 3 percent of GNP would be equal to about 20 percent of exports. While a 3 percent "tax" on increases in GNP would certainly not discourage the Brazilian government from pursuing higher GNP leve1s, a 20 percent "tax" on exports might well be a disincentive to exporting.

There are, of course, many important issues in resolving the overall problems of the debtor countries that will not be dealt with in this paper. What, for example, is the appropriate role of conditionality in lending and how is it best administered in the context of a long-term rescheduling plan like GNP-capping? ${ }^{6}$ Who will buy the exports of the debtor nations? What changes in the domestic policies of the debtor nations would encourage exports and reduce the amount of foreign exchange required at each rate of economic growth?7 What combination of policies would be most likely to raise the welfare of the debtor countries? 8 Only by ignoring these important general issues can the paper focus on the basic analytic problem of identifying the 
conditions under which the three key goals of cooperative debt management can be reconciled.

\section{The Economic Growth Requirement}

Experience shows that the level of GNP in developing countries is limited by the volume of imports. ${ }^{9}$ A lower level of imports limits the availability of needed equipment, parts and raw materials that are not available in the country and therefore reduces the economy's ability to produce from its domestically available inputs. Moreover, governments that wish to reduce imports of consumer goods are often forced to rely on contractionary macroeconomic policies that reduce overall demand in general.

Over time a government can in principle reduce its reliance on imports by the pursuit of policies that stimulate import substitution. However, such policies generally introduce inefficiences of their own that reduce output and even the rate of economic growth. 10 Moreover, the Latin American debtor countries generally have relatively low import-GNP ratios already because of a past pursuit of import substitution policies.11 A conservative assumption is that these import-GNP ratios cannot be reduced without depressing income and that future imports must grow at the same rate as GNP.

More formally, the relation between the level of real GNP $(x)$ and imports can be approximated as a linear function of the flow of imported materials $\left(I_{m}\right)$ and the net stock of existing imported equipment $\left(S_{I E}\right)$

$$
X=a_{0}(t)+a_{1} I_{m}+a_{2} S_{I E}
$$


where $\alpha_{0}(t)$ is a function of time that reflects the levels of domestic inputs and of technology. 12 From this it follows that the rate of growth of real GNP satisfies

$$
\frac{\dot{x}}{x}=\frac{\dot{\alpha}_{0}(t)}{X}+\alpha_{1} \frac{\dot{I}_{m}}{I_{m}} \frac{I_{m}}{x}+\alpha_{2} \frac{\dot{S}_{I E}}{X} .
$$

But the increase in the stock of imported equipment $\left(\dot{S}_{I E}\right)$ equals the flow of equipment imports minus the depreciation of the existing equipment stock:

$$
\dot{S}_{I E}=I_{E}-\delta S_{I E} .
$$

Substituting (3) into (2) and using (1) to elminate $S_{I E}$ implies:

$$
\frac{\dot{x}}{x}=\beta_{0}+\alpha \frac{\dot{I}_{m}}{I_{m}} \cdot \frac{I_{m}}{x}+\alpha_{1} \delta \frac{I_{m}}{x}+\alpha \frac{I_{E}}{x}
$$

where $\beta$ is a constant if $\alpha_{0}$ grows at a constant rate. The assumption that material imports grow at the same rate as GNP implies that (4) can be rewritten as:

$$
\frac{\dot{x}}{x}=\frac{\beta_{0}+\alpha_{1} \delta-\frac{I_{m}}{x}+\alpha_{2} \frac{I_{E}}{x}}{1-\alpha_{1} \frac{I_{m}}{x}}
$$

The rate of growth of real GNP depends on the ratios of material imports to GNP and equipment imports to GNP. To simplify the analysis that follows, I drop the distinction between the two types of imports and write

$$
\frac{\dot{x}}{x}=\phi\left(\frac{I}{x}\right) \text {. }
$$

The value of imports is linked to the need for additional borrowing by the current account balance equation: 


$$
I+i D=E+\dot{D}
$$

imports plus interest on the outstanding international debt (the product of the interest rate $i$ and the value of the debt (D)) must be financed by the combination of exports $(E)$ and the increase in the value of the debt $(\dot{D})$. Note that the annual debt service payment $(S)$ is the difference between the interest obligation (iD) and the net additional credit (D) extended to the debtor nation:

$$
S=i D-\dot{D}
$$

If the politically required rate of GNP growth in the debtor country is $g^{\star}$, equation (6) implies that a minimum acceptable level of imports, I*, is defined implicitly by

$$
g \star=\phi\left(\frac{I \star}{X}\right)
$$

Combining this with the current account balance condition (equation (7)) and the debt service identity (equation (8)) implies that the growth requirement that $\dot{x} / x>g *$ is equivalent to

$$
S \leqslant E-I * .
$$

Thus debt service must be less than the difference between the debtor country's exports and the level of imports required to achieve the required rate of growth. Since the ability to service debt while maintaining a desired rate of economic growth could be enhanced by increasing exports and by reducing import dependence, the assumption that the ratio of exports to GNP and the ratio of required imports to GNP both remain constant is a conservative one. With this assumption, the debt service limit of equation (10) can usefully be rewritten 


$$
\frac{S}{X} \leqslant \frac{E}{X}-\frac{I^{*}}{X}
$$

or simply

$$
s<s * x .
$$

Brazil, for example, has recently announced that it is aiming for a 7 percent rate of real GNP growth and that this is consistent with debt service payments equal to 2.5 percent of GNP. In the current notation, $g^{\star}=0.07$ and $s^{*}=0.025$.

The important question that requires analysis is whether the limit on debt service implied by the politically mandated rate of economic growth is consistent with the commercial banks' need for declining ratios of LDC debt to the banks' capital and earnings and to the GNPs and exports of the debtor countries. Before turning to that analysis, it is useful to consider the second aim of the debtor countries: to maintain a flow of additional resources from the creditor countries to the debtors.

\section{The Resource Transfer Constraint}

The resource transfer constraint is more difficult to specify than the politically required minimial rate of economic growth. Economic growth and the associated change in the population's standard of living is directly experienced by the public and can therefore impose a strong constraint on the actions of an elected government. In contrast, the notion of an additional and independent constraint on the net transfer of resources from the creditors is a bargaining issue that the policy officials impose on themselves.

The mildest form of such a resource transfer constraint is the 
requirement that the creditors not only reschedule any principal payments that come due but also extend additional credit so that the annual debt service payments are less than the accrued interest. The implication of this, that the stock of debt is growing $(\dot{D}>0)$, will generally not be an effective constraint because it is already implied by the limit on annual debt service that is necessary to achieve the required rate of economic growth. More specifically, equations (8) and (10) imply that

$$
\dot{D}>I^{*}+i D-E \text {. }
$$

The growth of the debt must be at least as large as the current account deficit at the level of imports required to achieve the politically mandated level of economic growth. Unless the level of exports of the debtor country are sufficient to finance both the interest on the existing debt and the growth-determined level of imports, the growth requirement will imply a growing level of debt.

In Brazil, for example, the external debt is currently about 43 percent of GNP $(D=0.43 x)$, the interest rate is approximately 10 percent $(i=0.1)$ and the acceptable debt service level is $E-I^{\star}=0.025 \mathrm{X}$. Together these imply that $\dot{D}$ equals $0.018 x$. The debt must currently grow at a rate that equals 1.8 percent of GNP. The mild resource transfer constraint that $\dot{D}>0$ does not currently imply an additional requirement. 13

It follows directly from the definition of the debt service ( $S=i D-\dot{D}$ ) that a resource transfer requirement that the debt be allowed to grow is equivalent to the constraint that the ratio of debt service to GNP be less than the product of the interest rate and the debt-GNP ratio. For Brazil, 
this is 0.043 and therefore greater than the maximum debt service ratio of 0.025 implied by the growth requirement.

An alternative and more stringent definition of the resource transfer constriant would be a requirement that the real value of the debt increase. Since the debt is denominated in dollars, this is equivalent to the requirement that

$$
\frac{\dot{D}}{\mathrm{D}}>\pi
$$

where $\pi$ is the rate of inflation in the United States. 14 Whether or not this is a binding constraint depends on whether the increase of the debt implied by the growth requirement (shown in equation (13)) is greater than the product of the U.S. inflation rate and the existing debt, i.e., on whether

$$
I^{*}+i D-E>\pi D \text {. }
$$

In the case of Brazil, I* $+i D-E=0.015 x$. Since $D=0.043 x$, inequality (15) fails if $\pi$ exceeds 0.042 . Although inequality (15) is satisfied at the 1986 inflation rate, it might not be if the inflation rate increases in the future unless the nominal interest rate also rises.

If inequality (15) is not satisfied, the maximum debt service payment is determined by the real resource transfer requirement (inequality (14)) rather than the economic growth constraint (inequality (11)). Combining (14) with the debt service identity (equation (8)) implies:

$$
\frac{5}{x}<(i-\pi) \frac{D}{x}
$$

The ratio of debt service to GNP must be less than the product of the real interest rate and the debt-GNP ratio. For Brazil, with $D / X$ currently 0.43 , an 
interest rate of 10 percent and a U.S. inflation rate of 4 percent imply that the debt service payments must be less than 2.6 percent of GNP.

The most extreme resource transfer constraint would be the requirement that the additional lending be sufficient to finance all of the accruing interest: $\dot{D}>i D$. This implies that the net transfer of resources is from the creditors to the debtors or, equivalently, $s<0$. This would clearly be binding in the case of Brazil. More generally, this constraint would be binding unless the debtor country's exports were not even sufficient to finance the imports needed for the required rate of growth ( $E<I^{*}$ ).

In short, depending on the way that the required net resource transfer is defined, the binding constraint on debt service as a share of GNP may be either the resource transfer requirement or the need to finance the imports associated with the required rate of economic growth. The key issue is whether this limit on debt service is compatible with the commercial banks' need for the debt to decline relative to bank assets and earnings and relative to debtor country GNP and exports. That is the subject of the next section.

\section{The Bank Exposure Ratios}

The most commonly cited measure of the commercial banks' LDC debt exposure is the ratio of that debt to the banks' own net capital. The emphasis on this measure is implicitly based on the assumption that the financial market's perception of the commercial banks' creditworthiness depends on the ability of the banks to withstand a default on the principal of those loans. Such an assumption is likely to be wrong for two reasons. 
First, the basic aim of the debt management strategy is not the ultimate repayment of the oustanding principal but rather an evolution to a situation in which the debtor countries can increase their debt on a voluntary market basis. Second, as the experience of the past four years shows, the outright repudiation of principal is a far less likely risk than arrearages on interest payments and unilaterally imposed limits on annual debt service payments. The basic risk that the commercial banks face is not the possibility that principal will not be repaid (since such repayment is not expected) but that the anticipated interest income stream will not be forthcoming. These considerations suggest that the relevant measure of the riskiness of the commercial banks' LOC debt exposure is the ratio of annual interest obligations to the banks' overall earnings flow.

The appropriate focus on the annual interest payments rather than on the principal of the loan also implies that the perceived soundness of the commercial banks' position depends on the prospects that the debtor countries will be able to make those interest payments rather than on their ability to repay ultimately the principal of the loans. The perceived creditworthiness of the commercial banks therefore depends on the likely trend in the interest burden of the debtor countries in relation to their overall GNP and exports.

We can summarize these aims of the commercial banks by asking whether the limits on debt service implied by the LDC debtors' growth requirement and resource transfer requirement are consistent with (1) a declining trend in the ratio of the LDC debt annual interest costs to the earnings of the commercial banks (iD/A where $A$ is the current annual earnings of the commercial banks) and (2) a declining trend in the ratio of LOC annual interest costs to the GNP and exports of the debtor countries $(i D / X)$. 


\subsection{Interest Accruals Relative to Bank Earnings}

Consider first the trend in the ratio of the LDC annual interest accruals to bank earnings. Although the interest rate on the LDC debt can fluctuate, it cannot experience a significant trend over time. It is sufficient therefore for the current analysis to consider the trend in the ratio of the LDC debt to commercial bank earnings. Similarly, although there may be annual fluctuations in bank earnings, the trend rate of growth of those earnings should equal the rate of growth of nominal GNP in the United States. The first compatibility question is therefore whether the rate of growth of the debt implied by the debtors' growth requirement and resource transfer requirement is less than the growth rate of U.S. nominal GNP.

If the U.S. nominal GNP growth rate is represented by $g+\pi$ where $g$ is the real growth rate in the U.S. and $\pi$ is again the U.S. rate of inflation, the growth of the LDC debt is less than the growth of U.S. nominal GNP if $\dot{D} / D<g+\pi$. Since the minimum growth requirement implies (according to equation (13)) that $\dot{D}>I^{*}+i D-E$, the two are compatible if and only if

$$
(g+\pi) D>i D+I^{*}-E \text {. }
$$

or, equivalently,

$$
(i-\pi-g) D<E-I * \text {. }
$$

The U.S. real interest rate will in general exceed the real U.S. rate of growth while the debtor country exports will generally exceed the required imports. Both sides of the inequality are then positive and the compatibility cannot be established without reference to the actual numerical values for 
particular countries. It is clear from (18), however, that the likelihood of compatibility is increased by a high value of exports relative to required imports and by a low initial value of debt.

Since the U.S. real growth rate has averaged approximately 3 percent in each of the past three decades, it is reasonable to take $g=0.03$. An interest rate of $i=0.10$ and an associated inflation rate of $\pi=0.04$ imply that the interest rate exceeds the nominal growth rate by 0.03 . Since this difference is relatively high in comparison to most years since 1950, a return to previous real interest levels would increase the likelihood of satisfying the compatibility condition of (18).

As noted above, in Brazil $D / X$ is currently about 0.43 while $(E-I) / X=0.025$. Combining these figures with $i-\pi-g=0.03$ shows that the compatibility condition of $(18)$ is currently easily satisfied for Brazil. There is no inconsistency between the increase in debt needed to sustain the required rate of economic growth and the limit on the rise in debt needed to shrink the ratio of debt to the earnings of the commercial banks. Moreover, the condition could be expected to hold even more easily in the future if the real interest rate and the ratio of debt to GNP decline while exports relative to necessary imports increase.

Consider next the compatibility of a declining ratio of debt to bank earnings and the real resource transfer requirements discussed in section 3 above. A potential conflict arises only when the real resource transfer constraint implies a greater increase in debt than is implied by the required rate of economic growth. Thus the requirement for some additional net lending $(\dot{D}>0)$ is likely to be dominated by the increase in debt needed to support the required rate of economic growth. But taken by itself the requirement 
that $\dot{D}>0$ is obviously compatible with the condition that the debt grow more slowly than U.S. nominal GNP since the two together are satisfied as long as U.S. nominal GNP is increasing.

Consider therefore the more stringent requirement that the real value of the debt increase: $\dot{D} / D>\pi$. This is compatible with the requirement that debt grow more slowly than U.S. nominal GNP $(\dot{D} / D<g+\pi)$ as long as the real growth rate in the U.S. is positive. Again there is no conflict between the desire for a declining ratio of debt to bank earnings and the resource transfer constraint.

In contrast, the extreme resource transfer constraint that would require the creditors to finance all of each year's annual interest liability would generally be incompatible with a declining ratio of debt to bank earnings. If the debtors are precluded in this way from making any resource transfer to the creditors during an extended period of time,15 the debt must grow at a rate that is a least equal to the rate of interest $(\dot{D} / D>i)$. Since the interest rate generally exceeds the nominal growth rate, this constraint is incompatible with a declining ratio of debt to bank earnings. It is possible but unlikely that this would be reversed by a future decline in real U.S. short-term interest rates in general and in the risk-induced spread between the rates on domestic loans and loans to debtor countries. But unless that happened, a constraint of "no resource transfer" from debtors to creditors would have to be rejected as incompatible with the requirement of maintaining bank creditworthiness or would have to be accommodated by reducing the rate at which interest accrues to something less than the nominal GNP growth rate.16 


\subsection{Interest Accruals Relative to Debtor Nation GNP}

The perceived financial soundness of the creditor banks reflects not only their ability to withstand delays and defaults on anticipated annual interest payments but also the ability of the debtor nations to continue to make those annual interest payments. This is only possible for each country if future annual interest accruals do not grow more rapidly than the debtor country's ability to meet those obligations. Since the debtor country must finance its international interest obligations by a trade surplus, the growth of interest.

must be less than the growth of net exports. As already noted, the assumption that future net exports will grow at the same rate as GNP is a conservative one since exports of the troubled debtor countries are now typically a quite small share of their GNP that can be raised by shifting from the past policy of import substitution and domestic protection to a policy that explicitly seeks increased trade. 17

Defining the ability to finance future interest accruals in this way implies that the banks' goal is a declining ratio of the debtor country's debt to its GNP. Since the debt is denominated in dollars, the relevant ratio is the real value of the debt $(D / p$ where $p$ is the level of U.S. prices) relative to the real value of the debtor country's GNP $(X)$. This real debt to GNP ratio $(\mathrm{D} / \mathrm{pX})$ will decline if

$$
\frac{\dot{D}}{\mathrm{D}}<\pi+\frac{\dot{\mathrm{x}}}{\mathrm{X}} \text {. }
$$

where $\pi$ is the U.S. inflation rate and $\dot{x} / X$ is the rate of real GNP growth in the debtor country. This is compatible with the growth of debt needed to finance imports (equation (13) of section 1) if and only if 


$$
\left[\frac{\dot{x}}{x}+\pi\right] D>i D+I *-E .
$$

This condition is analogous to the condition for a declining ratio of debt to bank earnings given in (17). They differ only because condition (20) incorporates the real GNP growth of the debtor nation where (17) incorporates the real GNP growth rate of the United States. Since the long-term GNP growth rates of the debtor countries have been and are likely to remain higher than the U.S. aggregate GNP growth rate, a declining ratio of debt to bank earnings is likely to imply a declining ratio of debt to debtor GNP. 18

The compatibility of the resource transfer requirement with a declining debt to GNP ratio is also analogous to its compatibility to a declining ratio of debt to bank earnings. Thus a declining ratio of debt to debtor GNP is compatible with an increasing real value of the $\operatorname{debt}(\dot{D} / D>\pi)$ as long as the real long-term growth rate of the debtor country's GNP is positive. Indeed, even the "no resource transfer" constraint that the growth of the debt must finance all accruing interest $(\dot{D}>i D)$ is compatible with a declining ratio of debt to debtor GNP if the real growth rate of the debtor country exceeds the U.S. real interest rate, a condition that generally does not hold now but that might hold in the future if U.S. real interest rates decline.

\section{The Situation in Brazil, Argentina and Mexico}

This paper has examined the conditions under which sustained economic growth in the LDC debtor nations can be compatible with enough debt service to increase the creditworthiness of the creditor banks. A potential conflict 
arises because economic growth in the debtor countries requires a level of imports that can in general only be financed by additional overseas borrowing. That conflict can in principle be resolved by restricting the annual debt service payments of the debtor nation to an agreed fraction of its GNP with any additional accrued liability added to the unpaid principal.

The analys is in the present paper has shown how the ratio of debt-service to GNP might be set in a way that is compatible with providing enough credit to finance the required level of economic growth while also reassuring financial markets by gradually reducing the ratio of the LDC debt to commercial bank earnings and to the debt service capacity of the debtor nations. Even an additional political constraint imposed by the debtor nations on the magnitude of the continuing resource transfer from the creditors need not be incompatible with gradually shrinking the relative size of the debt.

Compatibility is, however, an empirical issue that must be examined on a country by country basis. The example in the previous three sections showed that the current conditions in Brazil are such that the banks' need for declining ratios of debt to earnings and debt to debtor country GNP are compatible with providing enough credit for Brazil's real GNP to expand at 7 percent and for Brazil's debt to the rest of the world to go on increasing in real terms.

Table 1 shows that data required to make similar calculations for Argentina and Mexico. For comparison, the data for Brazil are also presented. Column 1 shows the 1984 ratio of international debt to GNP. The analys is simplifies by combining debt to governments and international agencies with 
commercial debt and by not distinguishing debt denominated in other creditor country currencies from dollar-denominated debt. Columns 2 and 3 show the 1984 ratios of export earnings to GNP and imports to GNP. These ratios are all derived from data given in the statistical appendix to the 1986 Annual Report of the International Bank for Reconstruction and Development. The fourth column indicates a "required" rate of real economic growth recently asserted by each debtor country; the sources of these required rates of return, their relation to recent experience, and their implications for the investment-GNP ratio are discussed below.

\subsection{Brazil}

A comparison of the 1986 Brazilian debt-GNP ratio of 0.43 referred to in earlier sections with the data for Brazil in Table 1 show that Brazil's debt to GNP ratio has fallen significantly in the past two years (from 0.53 to $0.43)$. This reflects a combination of factors: economic growth in Brazil, the magnitude of Brazil's current account surpluses, the changes in the exchange rate between the dollar and the currencies in which some of Brazil's debt is denominated, etc.

Brazil's recently announced growth target of 7 percent represents a substantial increase over the 4.4 percent annual average experienced between 1973 and 1984 although it is not as high as the 9.8 percent experienced in the period from 1965 through 1973. The Brazilians estimate that this growth requires limiting debt service to 2.5 percent of GNP.19 If exports continue at 14 percent of GNP, this debt service level implies a rise in imports from the 8 percent of GNP in 1984 to 11.5 percent of GNP. Since the real volume of 


\begin{abstract}
Table 1
Critical Ratios for Key Debtor Countries
\end{abstract}

\begin{tabular}{lcccc}
\hline $\begin{array}{c}\text { External } \\
\text { Debt } \\
\text { to GNP } \\
(1)\end{array}$ & $\begin{array}{c}\text { Exports } \\
\text { to GNP }\end{array}$ & $\begin{array}{c}\text { Imports } \\
\text { to GNP } \\
(2)\end{array}$ & $\begin{array}{c}\text { Target } \\
\text { Growth } \\
\text { Rate } \\
(4)\end{array}$ \\
\hline Brazil & & & & 0.07 \\
Argentina & 0.53 & 0.14 & 0.08 & 0.06 \\
Mexico & 0.60 & 0.10 & 0.06 & 0.04 \\
& 0.57 & 0.14 & 0.07 & \\
\hline
\end{tabular}

The figures in columns 1 through 3 are for 1984 . The target growth rates are based on plans announced in 1986. 
Brazil's imports in 1984 was 30 percent below the level of a decade earlier, such an increase in imports is not surprising.

The calculations in earlier sections of this paper showed that Brazil's desire to limit debt service to 2.5 percent of GNP is not inconsistent with the goals of reducing the ratio of Brazil's external debt to bank earnings and to Brazilian GNP. More specifically, that analys is indicated that the combination of a debt service of 2.5 percent of GNP and a debt to GNP ratio of 0.43 implies that the debt will grow at 4.2 percent. 20 This dominates the resource tranfer requirement that the real value of the debt must increase, i.e., that the nominal value of the debt must grow at 4 percent. It is also clearly compatible with the requirement that the nominal value of the debt grow more slowly than bank earnings (taken as the nominal rate of growth of the U.S. economy) and therefore with the requirement that Brazil's ratio of debt to GNP continue to decline (i.e., that the debt grow more slowly than the sum of the U.S. inflation rate and the real rate of growth in Brazil).

It is interesting to ask how high an import-GNP ratio Brazil could have and still have a rate of debt growth that is consistent with improving the banks' financial ratios. The key requirement for this is that the rate of growth of Brazil's debt be less than the long-term rate of growth of U.S. bank earnings or, equivalently, the rate of nominal GNP growth in the United States. Taking that growth rate to be 7 percent means that the Brazil's imports must be consistent with $\dot{D}<0.07 \mathrm{D}$. Using the current account constraint (that $\dot{D}=i D-E+I$ ) and substituting the relevant ratios for Brazil $(D=0.43 x, i=0.1$ and $E=.14 x)$ implies that the maximum value of $I / X$ would be 12.8 percent. Stated somewhat differently, the minimum level of debt 
service that would be compatible with improving the banks' financial ratios would be 1.2 percent of GNP.

\subsection{Argentina}

The Argentine government announced a GNP growth target of 6 percent in July 1986,21 but did not indicate an import level or debt service limit that it believed to be consistent with that rate of growth. Argentina's imports in 1984 were 6 percent of its GNP, a volume that was 10 percent below the level of a decade earlier. In assessing this, it is noteworthy that Argentina's real GNP was essentially unchanged over this period, having declined by an estimated 4 percent.

Consider then the implications of raising the import-GNP ratio from 0.06 to 0.075 while keeping the export ratio unchanged at 10 percent of GNP. With a debt to GNP ratio of 0.60 and an interest rate of 10 percent, the current account constraint implies that $\dot{0}=0.035 \times$. A comparison of this growth of the debt with the debt-GNP ratio of 0.60 implies that the annual rate of growth of the debt would.be 5.8 percent, substantially higher than the level needed to achieve an increase in the real value of the debt and yet below the 7 percent rate of increase needed to improve the banks' financial ratios. In short, even a substantial one-fourth increase in Argentina's ratio of imports to GNP (and the associated halving of its trade surplus) would be consistent with the banks' needs for declining ratios of Argentina's debt to bank earnings and to Argentina's GNP.

The maximum level of imports consistent with keeping Argentina's debt rate growth to less than 7 percent is 8.2 percent of GNP, substantially below 
Brazil's 12.8 percent because of Argentina's lower export-GNP ratio and greater debt service requirements. It is Argentina's higher ratio of debt to GNP that accounts for the higher minimum ratio of debt service to GNP in Argentina ( 1.8 percent) than in Brazil ( 1.2 percent).

\subsection{Mexico}

The sharp fall in the price of oil in early 1986 caused a substantial deterioration in Mexico's level of economic activity and in its ability to service its international debt. After growing at a rate of five percent from 1973 through 1985, output fell sharply in the first half of 1986 . In its 1986 negotiations with the IMF and creditor banks, Mexico insisted on obtaining enough credit to achieve a 3 percent real growth in 1987.22

The fall in Mexico's oil exports made it impossible to continue the combination of debt service and imports at their previous levels. Imports had grown 37 percent in real terms in the previous decade and were 7 percent of GNP in 1984. With 1984 merchandise exports twice the level of imports, the trade surplus contributed 7 percent of GNP to debt service.

With oil representing about two-thirds of Mexico's exports, a 50 percent fall in the price of oil would cut those export earnings by approximately one-third, from 14 percent of GNP to 9.3 percent of GNP. The trade surplus would fall from 7 per cent of GNP to 2.3 percent of GNP. Are these ratios consistent with improving the banks financial ratios for Mexico?

The combination of a trade surplus of 2.3 percent of GNP, a debt-GNP ratio of 0.57 and a 10 percent interest rate imply that the debt would grow at a 6.0 percent annual rate, far in excess of the amount required to maintain a 
growing real value of Mexico's debt but less than the critical 7 percent rate of increase needed to shrink the level of Mexico's debt relative to commercial bank earnings and to Mexico's own GNP and exports. 23

\section{Concluding Comment}

This paper has focused on the fundamental question of whether the increases in foreign debt required to sustain economic growth in the debtor nations are compatible with the declining ratios of debt to bank earnings and of debt to the GNPs of the debtor countries that are needed to strengthen the credit standing of the commercial banks. This question is central to developing a cooperative management of the international debt problem that avoids both unilateral debt repudiation by borrowers and unilateral credit interruption by creditors. The analysis has shown that these goals of growth and debt service are in principle compatible and that, with existing interest rates and debt ratios, that compatibility does in fact prevail for Brazil, Argentina and Mexico.

There are of course many things that are not discussed in this paper and that could be done to ameliorate the outlook for the international debt situation. A variety of changes in domestic policies in the debtor countries could increase economic growth, expand exports and reduce the need for additional borrowing. The special roles of the IMF and the World Bank are also not considered; their lending is simply assumed to expand at the same rate as the lending of the commercial banks.

Implicit in the analysis of the present paper is the notion that a 
tradeoff exists between the rate of economic growth of the debtor country and the rate at which the banks' financial ratios improve. This is clearly true in the short run since an increased rate of economic growth requires increased imports and therefore a more rapid rise in debt. Over the longer-run, however, this tradeoff is more complex since faster economic growth in the debtor country reduces the future ratio of debt to GNP and may enhance its capacity to export. The nature of the long-run tradeoff and the choice among compatible combinations of debtor country economic growth and the improvement of the banks' financial ratios deserves further attention.

The present analysis has also ignored the problem of uncertainty about future interest rates and international prices. One effect of limiting debt service to a percentage of GNP is that it automatically and fully adjusts the amount of credit extended for changes in the rate of interest. Since world interest rates are outside the control of the debtor countries, there is no adverse incentive on debtors created by this adjustment. There is, however, a new source of volatility in the net incomes of the banks that must borrow to obtain their funds and then cannot recover these additional funds from the debtor countries. More generally, the ratio of required debt service payments to GNP could be adjusted for changes in the prices of the imports and exports of the debtor countries or for changes in the level of activity in the industrial countries that alter the exports of those debtor countries. Full adjustment could protect the rates of economic growth in the debtor countries but at the cost of exposing the banks' financial ratios to unexpected fluctuations. The appropriate adjustment of the annual debt-service ratios to these fluctuations in the world economic environment is a subject that 
deserves future analysis.

There is finally the strategic question of whether a long-term agreement with automatic but limited capitalization of a portion of interest costs is a better way to obtain sound economic performance in the debtor countries than an ongoing process of frequent negotiations in which new credit is provided on an ad hoc basis. Such negotiations might be guided by the notion of limiting debt service to a fraction of GNP with special adjustments for changing conditions. Any attempt to answer this question lies beyond the scope of this paper. But the analysis developed here of whether growth in debtor countries is compatible with the improving financial ratios of the lender banks is equally relevant to formal plans to limit annual debt service and to the more informal system of frequent negotiations. 


\section{Footnotes}

1. See the discussion in Morgan Guaranty Bank (1983).

2. See Kyle and Sachs (1984) for evidence that the presence of troubled international debt has raised the cost of raising additional equity.

3. This is thus a generalization of the proposal to capitalize obligations arising out of interest rate increases above some fixed level. See feldstein (1984) and Bergsten, et al. (1985), pp. 41-50.

4. For a very useful analys is of a number of such possibilities, see Bergsten, et al. (1985), pp. 55-59.

5. See Bergsten et al. (1985), pp. 50-55.

6. On this subject, see Williamson (1984) and Sachs (1986).

7. Some of these issues are discussed in Cline $(1983,1984)$, Enders and Matione (1984), Feldste in (1984), Dornbusch (1985), and Sachs (1985).

8. Dornbusch (1985) emphasizes the important distinctions between the cashflow consequences of alternative policies and the impact of those policies on the welfare of the debtor countries.

9. The "two gap" model of development (Chenery and Strout, 1966) implies that GNP can be limited by either the volume of imports or the size of the domestic capital stock. More generally, a higher level of imports can contribute to the rate of economic growth even when it is not a binding constraint; see e.g., Levin and Robert (1983) and Bergsten et al. (1985). 10. On the deficiencies of import substitution policies, see Krueger (1983) and Sachs (1985).

11. The 1984 import-GNP ratios were only 0.081 in Brazil, 0.066 in Mexico and 
0.060 in Argentina (Internatonal Bank for Reconstruction and Development, 1986).

12. The analys is could easily be extended to include the link between GNP and the flow of imported consumer goods without changing the basic result derived be low.

13. This need not remain true; if $D / X$ declines over time, the resource transfer constraint may become binding and dominate the limit on the debt service implied by the economic growth requirement.

14. Some of the debt is in fact denominated in the currencies of other creditor countries. To the extent that that is true, the relevant constraint is defined by a weighted average of the creditor country inflation rates. 15. The debtors must of course plan to start paying interest at some point. A permanent agreement not to require any debt service is equivalent to forgiving the debt.

16. Senator Bill Bradley proposed in June 1986 that the banks reduce the rate at which interest accrues by 3 percentage points. This would have the effect of reducing the rate of interest below the rate of $U . S$. nominal GNP growth. If the 3 percent reduction were permanent, it would be equivalent to forgiving about 30 percent of the outstanding debt.

17. Exports now constitute only 14 percent of GNP in Brazil, 10 percent in Argentina and 14 percent in Mexico. In contrast, export oriented economies like Korea have developed export markets for 37 percent of their GNP. 18. An important difference is that the goal of a declining debt to bank earnings ratio refers to the combined debt of all of the debtor nations while the goal of a declining debt to GNP ratio refers to each country separately. 
It remains true however that faster economic growth in the debtor country than in the United States implies that import finance needs are compatible with a declining ratio of debt to debtor country GNP whenever import finance needs are compatible with a declining ratio of debt to bank earnings.

19. Dawnay (1986) reports the Brazilian government's announcement of these figures in July 1986 .

20. A debt service of 2.5 percent of GNP implies that $E-I=.025 \times$ and therefore, given the current account constraint of equation (7), that iD - $\dot{D}$ $=0.025 X$. With $D / X=0.43$ and an interest rate of 10 percent, $\dot{D}=0.018 X$. The rate of growth of the debt is thus the ratio $\dot{D}=0.018 x$ to $D=0.43 x$ or 0.042 .

21. See Coone (1986) for an account of Argentina's announcement and related economic conditions.

22. See Montagnon and Fleming (1986) for an account of these negotiations. 23. The Mexican situation is more favorable than this analys is implies because these merchandise trade figures exclude the important earnings from tourism. 


\section{References}

Bergsten, C. Fred et al. (1985), Bank Lending to Developing Countries: The Policy Alternatives (Washington, D.C.: Institute for International Economics).

Chenery, Hollis and A. Strout (1966), "Foreign Ass istance and Economic Development," American Economic Review 56:4, September 1966.

Cline, William R. (1983), International Debt and the Stability of the World Economy (Washington, DC: Institute for International Economics). Cline, William (1984), International Debt: Systemic Risk and Policy Response (Washington, DC: Institute for International Economics).

Coone, Tim, "Argentina Ponders Freeze on Foreign Debt Payments," Financial Times, August 7, 1986, p. 4.

Dawnay, Ivo, "Brazil Seeks to Limit Debt Service to $2.5 \%$ of GNP," Financial Times, July 30,1986, p. 4 .

Dornbusch, Rudiger (1985), "Policy and Performance Links Between LDC Debtors and Industrial Nations," Brookings Papers on Economic Activity $1985: 2$, pp. 303-56.

Enders, Thomas 0 . and Richard Mattione (1984), Lat in America: The Crisis of Debt and Growth (Washington, DC: The Brookings Institution). Feldstein, Martin (1984), "The International Debt Problem: From Crisis to Revenue Growth," Challenge, January/February.

International Bank for Reconstruction and Development (1986), Annual Report for 1986 (Washington, DC: International Bank for Reconstruction and Development). 
Krueger, Anne 0. (1983), Trade and Employment in Developing Countries 3:

Synthesis and Conclusions. Chicago: University of Chicago Press. Kyle, Steven and Jeffrey Sachs (1984), "Developing Country Debt and the Market Value of Large Commercial Banks," National Bureau of Economic Research Working Paper No. 1470.

Leven, Ronald and David Roberts (1983), "Latin America's Prospects for Recovery," Quarterly Review of the Federal Reserve Bank of New York 8:3, Autumn 1983.

Morgan Guaranty Trust (1983), "Global Debt: Assessment and Long-Term Strategy," World Financial Markets, June 1983, pp. 1-15.

Motagnon, Peter and Stewart Flemming, "Mexico Back at the Bankers' Doors," Financial Times, July 23,1986, p. 3.

Sachs, Jeffrey (1986), Conditionality and the Debt Crisis: Some Thoughts for the World Bank. Mimeo.

Sachs, Jeffrey, "External Debt and Macroeconomic Performance in Latin America and East Asia," Brookings Papers on Economic Activities 1985:2, pp. 523-573.

Williamson, John (1984), IMF Conditionality (Washington, DC: Institute for International Economics). 